Revista lus et Praxis, Año 20, No 1, 2014, pp. 39 - 66

ISSN 0717 - 2877

Universidad de Talca - Facultad de Ciencias Jurídicas y Sociales

"El riesgo de desarrollo en la responsabilidad

por productos del derecho colombiano"

Fabricio Mantilla Espinosa - Francisco Ternera Barrios

Trabajo recibido el 8 de julio y aprobado el 1 de noviembre de 2013

\title{
El riesgo de desarrollo en la responsabilidad por productos del derecho colombiano*
}

\author{
THE DEVELOPMENT RISK CLAUSE IN \\ COLOMBIAN PRODUCT LIABILITY LAW
}

\author{
FABRICIO MANTILLA ESPINOSA** \\ FranCISCO TeRnera BarRIOS***
}

\begin{abstract}
RESUMEN
Este ensayo, desde la perspectiva del derecho comparado, estudia la noción de riesgo de desarrollo, como causal de exoneración de responsabilidad por el hecho de los productos en el derecho colombiano. Partiendo de las nociones de "defecto" y "exoneración de responsabilidad", los autores analizan el alcance de las innovaciones incorporadas por el régimen de responsabilidad por el hecho de los productos defectuosos en un sistema cuyo fundamento se encuentra en el Código de don Andrés Bello.
\end{abstract}

ABSTRACT

This essay explores, from the perspective of comparative law, the notion of development risk as grounds for the exclusion of product liability under Colombian law. Based on the notions of "default" and "exclusion of liability" (or defense), the authors analyze the scope of the innovations incorporated by the products liability regime in a system that is based on the code of Andrés Bello.

Palabras clave

Responsabilidad por productos defectuosos, Derecho comparado, Negligencia, Daños, Causal de exoneración de responsabilidad.

* Todas las citas de textos en otros idiomas son traducciones libres.

Este artículo es un avance de la investigación sobre mecanismos alternativos de solución de controversias en el marco del proyecto "Los regímenes de indemnización de perjuicios". Los autores son investigadores de la línea de Derecho Civil del Grupo de investigaciones en Derecho Privado de la Facultad de Jurisprudencia de la Universidad del Rosario, institución que financia el proyecto.

Los autores agradecen muy especialmente a sus colegas y amigos Fernando Castillo Mayorga y Carlos Pizarro Wilson por sus valiosos consejos y críticas.

** Profesor de Carrera de la Universidad del Rosario. Master en Derecho Privado (Universidad de París II). Master en Derecho Civil (Universidad de París II). Master en Derecho Internacional Privado (Universidad de París II). Correo electrónico: fabricio.mantilla@urosario.edu.co,fabricio._mantilla@yahoo.fr.

*** Profesor de Carrera de la Universidad del Rosario. Doctor en Derecho (Universidad Alfonso X de Madrid). Master en Derecho Privado (Universidad de París II). Master en Derecho Administrativo (Universidad Alfonso X de Madrid). Master en Derecho Civil (Universidad de París II). Correo electrónico : francisco.ternera@urosario.edu.co, franciscoternera@yahoo.com. 


\section{KEYWORDS}

Products liability, Comparative law, Negligence, Damages, Grounds for exclusion of liability (defense)

La expresión "riesgo de desarrollo" es un neologismo críptico que, de entrada, antes que jurídico, parece sacado de un discurso activista ecologista o de una guía para padres de hijos púberes. Sin embargo, esta expresión ha sido acuñada por la doctrina ${ }^{1}$ para designar la institución consagrada en el literal E del artículo 7 de la Directiva 374 de 25 de julio de 1985 del Consejo Europeo (relativa a la aproximación de las disposiciones legales, reglamentarias y administrativas de los Estados miembros en materia de responsabilidad por los daños causados por productos defectuosos) $)^{2}$ :

En aplicación de la presente Directiva, el productor no será responsable si prueba: [...] e) o que, en el momento en que el producto fue puesto en circulación, el estado de los conocimientos científicos y técnicos no permitía descubrir la existencia del defecto [...].

El legislador colombiano, recientemente, adoptó una fórmula muy similar en el numeral 6 del artículo 22 de la Ley № 1480 de 12 de octubre de 2011 (por medio de la cual se expide el Estatuto del Consumidor y se dictan otras disposiciones $)^{3}$ :

Exoneración de responsabilidad por daños por producto defectuoso. Solo son admisibles como causales de exoneración de la responsabilidad por daños por producto defectuoso las siguientes: [...] 6. Cuando en el momento en que el producto fue puesto en circulación, el estado de los conocimientos científicos y técnicos no permitía descubrir la existencia del defecto. Lo anterior, sin perjuicio de lo establecido en el artículo 19 de la presente ley.

Ahora bien, la Directiva Europea incluyó esta causal de exoneración de responsabilidad propuesta por la delegación de Alemania ${ }^{4}$, país cuyo derecho interno la conocía ya, pero dejó la posibilidad a los países de la Unión de decidir si la adoptaban o no a través de las respectivas leyes introductorias.

"Fue la jurisprudencia alemana quien inventó la exoneración por el riesgo de desarrollo. Primero, se impuso al fabricante la obligación de respetar el 'estado actual de la técnica' para la elaboración de los productos. Después, se extendió la obligación a los conocimientos 'técnicos y científicos'. El importante

\footnotetext{
1 Véase a: VINEY (1998), p. 295.

2 Esta directiva fue modificada parcialmente por la Directiva 1999/34/CE que, básicamente, extendió la protección a los productos agropecuarios.

3 Una presentación concisa de los antecedentes de la ley en: Valbuena (2011), pp. 33-49.

4 Véase a : Viney y Jourdain (2006), p. 897 ; VINeY (1998), p. 296 ; Testu y MOITRY (1998), p. 12.
} 
fallo Hühnerpest de 1968 dispuso que si bien el fabricante tenía la obligación de respetar el estado de esos conocimientos, no se le podría reprochar culpa alguna por el 'defecto de desarrollo imprevisible de acuerdo con el estado de la técnica y la ciencia'" ${ }^{\prime \prime}$.

Después de la expedición de la Directiva, los distintos países europeos fueron, uno a uno, adoptándola mediante leyes internas: Alemania el 15 de diciembre de 1989 (modificada por el artículo 9 (3) de la ley de 19 de julio de 2002), Bélgica el 25 de febrero de 1991 (modificada por la ley de 12 de diciembre de 2000), España con la Ley No 22 del 6 de julio de 1994 (modificada mediante la ley 14 de 29 de diciembre de 2000), Italia con el DPR de 24 de mayo de 1998 (modificado mediante Decreto Legislativo $N^{\circ} 25$ del 2 de febrero del 2001), Francia con la Ley 389 del 19 de mayo de 1998, etc.

Europa generó, entonces, toda una normativa, tanto comunitaria como nacional, sobre la responsabilidad por los productos defectuosos, en general, y sobre el riesgo de desarrollo, en particular. Dicha normativa ha dado lugar tanto a una interpretación jurisprudencial comunitaria, por parte del Tribunal de Justicia de la Unión Europea ${ }^{6}$, como a un desarrollo jurisprudencial en cada uno de los Estados miembros. Adicionalmente, la doctrina no ha dejado pasar esta oportunidad para elaborar toda suerte de estudios sobre estas nuevas instituciones que resultan tan atractivas en teoría como útiles en la práctica ${ }^{7}$.

Pero Europa no fue la única en estructurar un régimen de responsabilidad por productos defectuosos con estas características. En efecto, los Estados Unidos de Norteamérica, el American Law Institute -ALI- ha ofrecido, en sus Restatement (Second) of Torts (1965) y Restatement (Third) of Torts (1997), section 2 (que regulan la responsabilidad por el hecho de los productos), una amplia jurisprudencia que confecciona el régimen jurídico aplicable a los products liability.

"La elección entre estas dos maneras de realizar el balance riesgos/beneficios [la apreciación ex ante y la apreciación ex post] plantea el problema de los riesgos de desarrollo. Éstos son habitualmente definidos como los defectos que presenta un producto y que no se podían conocer en el momento de su puesta

\footnotetext{
5 BerG (1996), p. 4. Un estudio completo sobre el derecho alemán en este punto en: BorGhetTı (2004), pp. 123-193; Ancel (2012).

6 Consúltese : VINeY (2002), pp. 1945-1948.

7 Véase a: Larroumet (1998 a), pp. 311-316; Viney (1998), pp. 291-299; Díez-Picazo (2011), pp. 465499; Alpa (2006), pp. 1032-1085; Mezzasoma (2012), pp. 211-254; Woolcott (2007), pp. 233-524.

8 Consúltese: Borghetti (2004), pp. 19-92; WoOlcott (2007), pp. 25-232; Coleman (2010), pp. 405-425; GUeRRA (2002), pp. 179-266; y COOTER y Ulen (1999), pp. 451-463.

Un claro y conciso análisis comparativo inglés norteamericano sobre este tema en: DeAKIN et al. (2003), pp. 603-644.
} 
en circulación, tomando en consideración el estado de los conocimientos científicos y técnicos de ese momento. El proveedor no está obligado a responder por esta clase de riesgos dentro del marco de un régimen de responsabilidad por culpa. Por el contrario, una apreciación ex post de la defectuosidad debería obligarlo a responder por ellos. A partir del momento en que el carácter conocido o previsible del riesgo deja de ser una condición de la responsabilidad del proveedor, éste no podría invocar el state of the art defense, nombre que los norteamericanos le dan a la exoneración por riesgo de desarrollo. Sin embargo, la jurisprudencia mayoritaria nunca ha asumido esta posición" ${ }^{\prime \prime}$.

Así las cosas, los países latinoamericanos, para la elaboración de sus regímenes de responsabilidad por productos defectuosos, han recibido influencias provenientes tanto del este como del norte ${ }^{10}$.

En el caso colombiano, estas influencias se cristalizaron en la Ley $N^{\circ} 1480$ de 2011'11, la cual reemplazó al Decreto 3466 de 1982 que, al igual que la Ley $N^{0} 19.496$ de Chile (1997)12, no regulaba directamente la responsabilidad del productor y tuvo que ver pasar múltiples proyectos de ley antes de ser derogado ${ }^{13}$.

Pero la influencia del derecho extranjero no se limitó al texto de la ley. En un célebre fallo de $2009^{14}$, la propia Corte Suprema de Justicia colombiana, ante la ausencia de normativa sobre la materia, se aventuró a proponer una definición del riesgo de desarrollo basándose en lo dispuesto por la Directiva Europea de 1985:

"Mención especial debe hacerse en torno a los llamados 'riesgos de desarrollo', que en la comentada Directiva fue concebida como una causal de exoneración. Se entienden por tales aquellos peligros que un producto entraña en el momento en el que se introduce en el mercado, pero que, dado el estado de la ciencia y de la técnica no eran cognoscibles y, por ende, previsibles, por el fabricante. $O$, para decirlo de otro modo, acaece esa causal de inimputabilidad cuando, conforme a los dictados de la ciencia o de la técnica, entonces en vigor, el producto se consideraba inocuo, pero que posteriores investigaciones demuestran que es dañoso".

\footnotetext{
9 Borghetti (2004), p. 60.

${ }^{10}$ Consúltese, a título de ejemplo: Picasso y Vázquez (2009); Mosset y Wajntraub (2008); Annicchiarico (2008), pp. 47-65.

11 Véase una presentación general de la ley en: Giraldo et al. (2012) y Díaz-Granados (2012 b).

${ }^{12}$ Consúltese al respecto: Barros (2007), pp. 748 a 770 y CAPrile (2008), pp. 561-602.

${ }^{13}$ Consúltese al respecto: GAVIRIA (2012), pp. XIII-XV.

${ }^{14}$ Corte Suprema de Justicia. Sala de Casación Civil. 30 de abril de 2009. M.P. Pedro Octavio Munar Cadena. Exp. 25899319399219990062901.
} 
Así y todo, establecer qué se entiende actualmente, en el lenguaje del derecho colombiano, por "riesgo de desarrollo" resulta tanto más difícil cuanto que, hasta donde tenemos conocimiento ${ }^{15}$, los jueces no han tenido aún oportunidad de usar la expresión para precisar su significado y su función efectiva en la práctica ${ }^{16}$. La Corte Suprema, en el citado fallo de 2009, no hizo más que proponer una definición basada en el derecho extranjero, pero, sin aplicarla -O descartarla- para resolver un caso concreto ${ }^{17}$.

Ahora bien, el legislador colombiano, en el artículo 22 del Estatuto del Consumidor, tomó claramente partido al permitir al productor obtener la "exoneración de responsabilidad" si logra probar que, cuando introdujo el producto en el mercado, "el estado de los conocimientos científicos y técnicos no permitía descubrir la existencia del defecto". En pocas palabras, en el derecho colombiano, como en tantos otros, se trataría de un defecto del producto que, por sus características especiales, no compromete la responsabilidad del productor por los daños causados.

La solución parece muy sensata, pero, si esto es tan evidente, ¿por qué nunca nadie había hablado en Colombia del famoso riesgo de desarrollo? ¿O tal vez se le llamaba con otro nombre? Y si fuera así, ¿cuál sería éste?

Para tratar de responder a estos interrogantes, es necesario analizar algunos vocablos utilizados en la ley colombiana cuya vaguedad y ambigüedad dificultan la comprensión de la noción de forma más precisa. Por nuestra parte nos concentraremos en las expresiones "defecto" (I) y "exoneración de responsabilidad" (II) ${ }^{18}$.

\footnotetext{
15 "Por lo que aquí nos interesa, ello lleva a que el uso de la jurisprudencia sea a menudo una empresa complicada, difícil y arriesgada. De un lado, en realidad, no se sabe casi nunca si de verdad se ha llegado a conocer toda la jurisprudencia (lo que suele ser imposible), o al menos toda la jurisprudencia relevante sobre una cuestión determinada. De otro lado, con frecuencia se descubre que la jurisprudencia es incoherente y contradictoria: se tratará, entonces, de establecer si hay o no hay jurisprudencia conforme, si hay una jurisprudencia prevaleciente, si la jurisprudencia es incierta, o incluso si hay una situación de caso jurisprudencial". TARUFFO (2009), p. 561.

16 "El significado de una palabra es su uso en el lenguaje". "Todo signo parece por sí solo muerto. ¿Qué es lo que le da vida? -Vive en el uso. ¿Contiene ahí el hálito vital?- ¿O es el uso su hálito?" WITTGensteIN (1988), Proposición 43, p. 61, y proposición 432, p. 309.

17 "La definición no explica la función efectiva de la palabra en el derecho; de ahí que la teoría basada sobre la definición no consigue ser una teoría del derecho existente. Esto es lo que hace que tales teorías sean inadecuadas". NAKHNIKIAN (1998), p. 40.

18 "Analizar una expresión no consiste en sustituirla por otras que se adecuen mejor a la estructura de los hechos y satisfagan nociones preconcebidas sobre la función ideal del lenguaje. Es, en cambio, tomar clara conciencia de la función que ella cumple en el contexto particular. Esto es, qué uso se le asigna en el lenguaje, entendido no ya como una herramienta apta para prestar un solo servicio, sino como un variado instrumental que empleamos para los fines más diversos". CARRIÓ (1962), p. 19.
} 
La Ley colombiana, al igual que la Directiva Europea, utiliza el vocablo "defecto" y no "riesgo", lo que resulta mucho más preciso. En efecto, por "riesgo" se entiende la "contingencia o proximidad de un daño"199, explicación que no parece dar muchas luces sobre el origen del daño contingente, y el precisar que este riesgo es debido al desarrollo ${ }^{20}$, tampoco resulta de gran ayuda para entender lo que se pretende expresar.

La palabra "defecto", en sus dos primeras acepciones del Diccionario de la Real Academia Española, significa "carencia de alguna cualidad propia de algo" e "imperfección en algo o en alguien"21. De esto podemos sacar dos conclusiones: la primera, que la definición exige una comparación y, la segunda, que la comparación tiene una valoración negativa ${ }^{22}$.

Tanto la carencia de alguna cualidad como la imperfección se establecen mediante comparación ${ }^{23}$ con otro objeto que tiene la cualidad que falta al objeto defectuoso; objeto que es perfecto, frente al defectuoso, que es imperfecto ${ }^{24}$.

Adicionalmente, el adjetivo "defectuoso" está lejos de ser neutro. "Defectuoso" no es simplemente incompleto, es mucho más que eso ${ }^{25}$. Cuando se califica algo de esta manera se considera que tiene un valor negativo, incorrecto, malo, en el entendido de que no satisface los criterios de bondad instrumental.

${ }^{19}$ Real Academia Española. Diccionario de la Lengua Española. Disponible en: http://lema.rae.es/ drae/?val=riesgo

Una clara presentación de la etimología del vocablo "riesgo" y sus distintos usos en el lenguaje del derecho privado en: VoIDEY (2005).

${ }^{20}$ Desarrollar: "[...] 2. tr. Acrecentar, dar incremento a algo de orden físico, intelectual o moral [...]". Real Academia Española. Diccionario de la Lengua Española. Disponible en: http://lema.rae.es/ drae/?val=desarrollar

${ }^{21}$ Real Academia Española. Diccionario de la Lengua Española. Disponible en: http://lema.rae.es/ drae/?val=defecto

22 Véase: Schopenhauer (1991), p. 97.

${ }^{23}$ Comparar: "fijar la atención en dos o más objetos para descubrir sus relaciones o estimar sus diferencias o semejanza". Real Academia Española. Diccionario de la Lengua Española. Disponible en: http://lema.rae.es/drae/?val=comparar

${ }^{24}$ Perfecto: "que tiene el mayor grado posible de bondad o excelencia en su línea". Real Academia Española. Diccionario de la Lengua Española. Disponible en: http://lema.rae.es/drae/?val=perfecto

25 "Conocer el significado descriptivo es conocer qué pautas está usando quien emite el juicio. Tomemos un caso en el que la pauta es bien conocida. Si un sacerdote dice de una muchacha que es buena, nos podemos formar una idea acerca de cómo es ella: pensaremos, por ejemplo, que concurre a la iglesia. Por eso es fácil caer en el error de suponer que, al decir que es una muchacha buena, el sacerdote quiere simplemente decir que ella tiene estas características descriptivas. [...] También se propone (means) encomiarla por tenerlas; y esta parte de lo que él quiere decir (hismeaning) es la primaria". HARE (1975), p. 142. 
En palabras de Georg-Henrik von Wright: "atribuir bondad instrumental a una cosa es primariamente decir que tal cosa sirve bien para un objetivo. Atribuir a alguna cosa la propiedad de tener una bondad propia de su clase presupone que existe una finalidad que está -diré- esencialmente asociada a ese género y que se cree que tal cosa sirve bien para esa finalidad" 26 .

Aclarado esto, nos resta establecer cuál es el objeto de comparación que debe servir para determinar si un producto específico es o no defectuoso. La Ley $\mathrm{N}^{\circ} 1480$ de 2011 trae una definición que nos facilita considerablemente la tarea: "Producto defectuoso es aquel bien mueble o inmueble que en razón de un error el diseño, fabricación, construcción, embalaje o información, no ofrezca la razonable seguridad a la que toda persona tiene derecho" (art. 5 Núm. 17).

De lo señalado se desprende que la comparación debe realizarse entre el producto específico y un objeto abstracto: el producto que ofrece la razonable seguridad ${ }^{27}$. Sin embargo, para precisar lo que se quiere decir mediante la expresión "seguridad razonable que debe ofrecer un producto", es menester establecer previamente frente a qué clase de riesgos.

En la sociedad contemporánea, los riesgos han evolucionado de forma notable, principalmente, debido a los nuevos usos de la tecnología y sus consecuencias ${ }^{28}$. Muchos de estos nuevos riesgos se materializan en productos elaborados de forma, más o menos, masiva, que, igualmente, pueden causar daños también, más o menos, masivos.

En términos generales, podemos identificar los riesgos cuya existencia era conocida, pero su presencia en un producto determinado no se podía establecer por razones técnicas (i) y los riesgos cuya existencia misma era desconocida en el momento de la puesta en circulación del producto (ii) ${ }^{29}$.

\footnotetext{
${ }^{26}$ VON WRIGHT (2010), p. 52.

${ }^{27}$ Las abstracciones, como el buen padre de familia y el producto que ofrece la razonable seguridad son hechos institucionales creados por el hombre mediante el lenguaje y tienen una forma de existencia distinta de la que tienen los hechos de la naturaleza. Tanto los unicornios como los caballos existen, pero, los primeros existen como símbolos y mitos, mientras que los segundos lo hacen de forma sensible. Véase al respecto: RyLE (2005), pp. 29-37.

${ }^{28}$ Véase al respecto: BЕсK (2006) y BeCK (2009).

Un claro y conciso análisis jurídico al respecto en: RochfeLD (2011), pp. 525-537.

${ }^{29}$ Véase: BORGHETtı (2004), pp. 400-401.

"Entre las diferentes acepciones de la noción, sólo el hecho dañoso que reúne las características del riesgo indemnizable puede dar lugar a la reparación. [...] El accidente ya no procede del riesgo - caso fortuito, justificado, durante mucho tiempo, mediante referencia a la voluntad divina y la fatalidad. Se admite que puede, también, ser la concreción de un riesgo debido a la actividad humana et, en sí, mucho más previsible estadísticamente y, en ciertos casos, incluso de manera individual. Esta nueva caracterización del hecho dañoso añade a la única que hasta entonces conocía el derecho civil: el riesgo - azar, el golpe de suerte que libera, principalmente, al deudor contractual [...]. El Código Civil había creado el derecho del caso fortuito. La doctrina y los jueces crearon el derecho del accidente
} 
(i) Los riesgos conocidos in abstracto pero que, por razones técnicas, no podían determinarse en un producto in concreto se materializan en ciertos ejemplares de un tipo de productos, los cuales tendrían mayores probabilidades de causar daños ${ }^{30}$, e implicarían una peligrosidad anormal ${ }^{31}$.

La ley italiana que incorporó la Directiva Europea dispuso claramente, en su artículo 5, numeral 3: "un producto es defectuoso si no ofrece la seguridad ofrecida por los otros ejemplares de la misma serie".

Ahora bien, para establecer que unos productos son normales y otros anormales, es necesario tener un parámetro de normalidad con el cual se va a hacer la comparación, el objeto abstracto e hipotético: el producto que ofrece la razonable seguridad. Como los riesgos en cuestión eran conocidos, el objeto abstracto se construye tomando en consideración estos riesgos, es decir, el producto que ofrece la razonable seguridad, entre otros, frente a esta clase de riesgos.

La jurisprudencia francesa, incluso desde antes de la promulgación de la ley que incorporó la Directiva Europea, se inclinó por esta posición. Veamos algunos ejemplos: en un fallo de 1 de julio de 1969 la Corte de Casación casó una decisión de la Corte de Apelaciones de Chambéry que había absuelto a un vendedor de quesos madurados, reblochons, contaminados con una bacteria. La Corte de Chambéry había fundamentado su decisión argumentando que "no se puede exigir a un vendedor de quesos de Saboya conocimientos profesionales superiores a aquéllos que poseen los especialistas en investigación con productos lácteos". La Corte de Casación consideró que esta decisión contradecía lo dispuesto por el artículo 1645 del Código Civil (garantía por vicios ocultos) y precisó que "aquél cuya profesión es vender productos por él fabricados tiene la obligación de conocer los vicios ocultos de la cosa vendida $[\ldots]^{\prime \prime 32}$.

previsible. Precisamente, de estas dos ramas fundamentales procede el árbol de la polisemia de la noción de 'riesgo', cuyo conjunto de ramas se articula principalmente alrededor de una dicotomía entre previsibilidad e imprevisibilidad del hecho dañoso". OIDEY (2005), pp. 25-26.

Véase también a: MARTIN (2009), pp. 1-12 y Cour de Cassation, Le risque, Rapport annuel 2011 (2012).

${ }^{30}$ Sin embargo, hablar de altas probabilidades de causar daños, tampoco parece aclarar mucho el panorama: “'Probablemente' implica 'posiblemente' y excluye 'seguramente', lo que es probable, ni es seguro ni imposible [...]. 'Probablemente' admite adverbios de comparación -la probabilidad es 'graduable'-. A la pregunta suplementaria '¿Cómo de probable?', siempre a punto después de que se ha hecho la aserción 'probablemente', se puede contestar con 'bastante probable', 'muy probable', 'casi seguro' e incluso, [...], con una indicación de oportunidades o suertes numéricas". BLACK (1984), pp. 89-92.

31 Véase: Epstein (1999), pp. 406-407.

${ }^{32}$ Cour de Cassattion. Com., 1 juillet 1969, Bull. Civ., IV, NN 243, citado por Borghettı (2004), pp. 404-405. 
En este mismo orden de ideas, en 1992, el máximo tribunal francés consideró que el vendedor de carne con salmonella debía responder por estos vicios ocultos frente el comprador que fabricaba con ella charcutería para vender al público ${ }^{33}$.

La Corte Suprema de Justicia colombiana en dos fallos célebres de 2009, también anteriores al Estatuto del Consumidor, a pesar de no condenar al productor, precisó claramente que a partir del momento en que el producto presenta un defecto que causa un daño, el productor debe responder, sin importar si, in concreto, podía o no identificar el mencionado defecto en algunos de los productos puestos en el mercado.

En el primer caso se trataba de una caja de leche que se había acidificado por contener ciertas bacterias. En el proceso se logró demostrar que otras cajas del mismo lote habían desarrollado el mismo tipo de microorganismos; sin embargo, la Corte confirmó el fallo de instancia que había negado la indemnización a la víctima porque el productor demandado logró demostrar que no había ningún vínculo causal entre las bacterias de la leche y los daños cuya reparación reclamaba la demandante ${ }^{34}$.

El segundo caso se presentó con ocasión de la intoxicación de unos caballos de exposición de un prestigioso criadero. La Corte casó la sentencia del juez de instancia que había condenado a la productora del alimento equino por no haberse demostrado el defecto del producto. De acuerdo con las pruebas aportadas al proceso, los animales se intoxicaron por unas micotoxinas que se desarrollaron, al parecer, por la incorrecta manipulación de los alimentos en el criadero mismo, pero no por un defecto propio del producto ${ }^{35}$.

En este orden de ideas, podemos afirmar que cuando los riesgos son conocidos in abstracto y se materializan in concreto, sólo en ciertos ejemplares de los productos, éstos no ofrecen la seguridad razonable que se espera de ellos, seguridad que deben ofrecer todos los productos de ese tipo y, difícilmente, se podría llegar a sostener que el estado de los conocimientos científicos y técnicos no permitía descubrir la existencia del defecto.

(ii) Los riesgos cuya existencia misma era desconocida en el momento de la puesta en circulación del producto pueden concretarse ya sea en ciertos ejemplares, como la sangre contaminada con VIH, antes de que la enfermedad

\footnotetext{
${ }^{33}$ Cour de Cassation. Ch. Com. 21 janvier 1992. SA Lachaise c/SA Faure Charcuterie Enval. Véase a: LeVeneur, (2002), pp. 580-582.

${ }^{34}$ Corte Suprema de Justicia. Casación Civil. 30 de abril de 2009. M.P. Pedro Octavio Munar Cadena. Exp. 25899319399219990062901.

${ }^{35}$ Corte Suprema de Justicia. Casación Civil. 24 de septiembre de 2009. M.P. César Julio Valencia Copete Exp. 05360-31-03-001-2005-00060-01.
} 
fuera identificada, a mediados de la década de $1980^{36}$, o bien en todos los ejemplares de cierto producto, como las fibras de asbesto que pueden producir cáncer pulmonar, asbestosis y mesotelioma. Éste es el campo de aplicación por excelencia de la exoneración por riesgo de desarrollo.

En Colombia, no parece haber antecedentes de este tipo que nos permitan analizar la posición de la jurisprudencia ${ }^{37}$, por tal razón, para ejemplificar estas hipótesis, nos remitimos al derecho comparado:

En 1980 la Suprema Corte de California, Estados Unidos, en el conocido caso de Sindell contra Abbott Laboratories ${ }^{38}$, condenó a las empresas productoras del medicamento antiabortivo DES, el cual aumentaba el riesgo de cáncer en mujeres cuyas madres lo habían consumido durante el embarazo, a pesar de que en el momento de la puesta del producto en el mercado las empresas productoras no podían razonablemente prever el daño que sólo se materializaría muchos años después.

El célebre fallo Hühnerpest de la jurisprudencia alemana -Bundesgerichtshof, 26 de noviembre de 1968- fue proferido con ocasión de la peste aviar que se propagó en la empresa de un criador de pollos, debido al defecto de esterilización de los frascos que contenían las vacunas que había utilizado en sus animales. A pesar de que, en este caso, la Corte condenó al productor, precisó que los productores no debían responder por los daños causados por los defectos de los productos cuando, en el momento de su puesta en circulación, aquéllos resultaban imprevisibles, de acuerdo con el estado de la técnica y la ciencia ${ }^{39}$. Como bien lo ha resaltado la doctrina ${ }^{40}$, esta decisión fue la piedra angular para la construcción del régimen de responsabilidad por productos defectuosos en Alemania y una de las principales fuentes de inspiración de la Directiva Europea de 25 de julio de 1985.

Una vez establecidos los riesgos, podemos tratar de precisar cuál es la seguridad razonable que debe ofrecer un producto frente a los riesgos que pueden

\footnotetext{
${ }^{36}$ En los Estados Unidos, ejemplos como el de la sangre contaminada no estarían cubiertos por el régimen de responsabilidad por productos defectuosos puesto que la sangre y el tejido humano no se consideran productos. Véase: EPSTEIN (1999), p. 396.

${ }^{37}$ Los hechos que dieron lugar al célebre caso de contaminación con VIH por la transfusión sanguínea realizada en una clínica de Bogotá se presentaron en 1989 y el Estado colombiano fue condenado por haber expedido licencia de funcionamiento y permitir el uso del sello nacional de garantía de la sangre (por VIH, VDRL y hepatitis B) a un centro bacteriológico que no cumplía con los estándares de calidad exigidos. Véase: Consejo de Estado. Sección. Tercera. 29 de enero de 2004. C.P. Alier Hernández. Rad: 0814.

${ }^{38}$ Disponible en: http://www.law.harvard.edu/publications/evidenceiii/cases/sindell.htm, Wells (1981); RosenKRANTZ, (1998); BarRía (2011) y BulLARD (2006), pp. 748-749.

${ }^{39}$ Véase Borghetti (2004), pp. 132-133.

${ }^{40}$ Véase: ANCEL (2012).
} 
preverse ${ }^{41}$. Sin embargo, "previsión razonable"42 está lejos de ser una expresión que nos permita establecer con relativa certeza cuáles daños causados por el producto estarían a cargo del productor ${ }^{43}$, y el estado de la técnica y la ciencia en el momento de la puesta en circulación del producto no siempre resulta fácil de determinar.

El 29 de mayo de 1997, el Tribunal de Justicia de la Unión Europea -TJUE-, en un caso que enfrentó a la Comisión Europea contra el Reino Unido, estableció los parámetros para precisar estos aspectos. Así, pues, el TJUE estableció: (a) que el análisis no debía hacerse in concreto, es decir, no debía tomarse en consideración el estado de conocimientos científicos y técnicos que el productor conocía o debía conocer, sino los conocimientos que se le presume tener; (b) que este estado de conocimientos no se limita al sector industrial dentro del cual opera el productor; (c) que el nivel de conocimientos exigido es el más avanzado que existía en el momento de la puesta en circulación y (d) que este nivel de conocimientos haya sido accesible -puesto en conocimiento del público y con una antelación razonable- ${ }^{44}$.

A diferencia de lo que sucede en la hipótesis de los riesgos conocidos in abstracto, para los riesgos desconocidos, la calificación de defectuoso se establece de forma retrospectiva, es decir, mediante comparación de un objeto abstracto presente con el producto elaborado anteriormente; sin embargo, para juzgar si el productor debe responder o no por los daños causados, se entra a juzgar el comportamiento mismo del productor. Para tal efecto, la decisión del TJUE estableció la forma de calificar la actuación circunstanciada del productor, mediante comparación con la actuación hipotética de un nuevo sujeto abstracto,

41 "De alguna manera como ya dijimos toda contingencia es previsible, incluso el evento más inusual pensable, puede ser previsto usando nuestra imaginación, si es que tenemos tiempo suficiente para dejarla recorrer el mundo de las posibilidades. El verdadero problema no es si la contingencia es algo que puede ocurrir, sino, si se justifica en términos de costos de transacción, contemplar su posible ocurrencia en el contrato y asignar los riesgos que de ella se deriven". BullarD (2006), p. 357.

42 “¿Qué se entiende por 'posibilidad de prever'? Debe tratarse de una previsibilidad absoluta, para la cual se debe estar siempre en condiciones de prever exactamente estas reacciones, o podemos estar satisfechos con una previsibilidad en algún sentido relativa, para la cual se admiten márgenes de error en el an y/o en el quid y en el quantum [...]? Gometz (2012), p. 44.

43 "Con esto quiero referirme al siguiente fenómeno: [...] el uso de una palabra tal como de hecho se la emplea, hace que sea incierta o dudosa la inclusión de un hecho o de un objeto concreto dentro del campo de acción de ella. Hay casos típicos frente a los cuales nadie en su sano juicio dudaría en aplicar la palabra en juego. Hay casos claramente excluidos del campo de aplicación del vocablo. Pero hay otros que, a diferencia de los primeros y de los segundos, no están claramente ni incluidos ni excluidos [...] Dichas palabras son periféricamente indeterminadas. Para incluir o excluir el caso marginal es menester tomar una decisión". CARRIÓ (1994), p. 137.

${ }^{44}$ Véase un análisis completo de la decisión en: Borghetti (2004), pp. 462-468 y Leveneur (1998), pp. 31-32. 
el productor conocedor de la ciencia y tecnología, quien vendría a ubicarse junto al buen padre de familia y el profesional avisado.

Ahora bien, en la descripción del nuevo sujeto abstracto, el Tribunal utiliza ciertas expresiones, como "el conocimiento más avanzado" y "accesible", cuya vaguedad confiere a los jueces de los Estados de la Unión una gran libertad en el momento de fallar los casos concretos ${ }^{45}$.

Por su parte, el Estatuto del Consumidor colombiano, como ya vimos, definió el producto defectuoso de la siguiente forma: "(...) aquel bien mueble o inmueble que en razón de un error el diseño, fabricación, construcción, embalaje o información, no ofrezca la razonable seguridad a la que toda persona tiene derecho" (art. 5 núm. 17 L. 1480/2011) e incluyó en esta definición los productos cuyos problemas de seguridad sólo pudieron descubrirse por los avances de la ciencia y la tecnología, pero olvidó hacer una precisión fundamental que se encuentra en el artículo 6 numeral 2 de la Directiva Europea: "Un producto no se considerará defectuoso por la única razón de que, posteriormente, se haya puesto en circulación un producto más perfeccionado"t46.

Esta disposición del derecho europeo permite precisar los contornos del productor conocedor de la ciencia y tecnología: se trata de un profesional muy bien informado y no de un especialista en ciencia ficción; un profesional que debe garantizar que sus productos ofrezcan la seguridad que puede esperarse por los riesgos conocidos, seguridad que ofrecen los otros productos del mismo tipo o que ofrecería una opción alternativa razonable, y no la supuesta seguridad que ofrecería un objeto futuro meramente imaginario.

En este orden de ideas, los automóviles no se volvieron todos defectuosos a partir del momento en que se inventaron los frenos ABS o los airbags. Sin embargo, el producto futuro que ofrecería más seguridad casi siempre se va concretando en una opción alternativa razonable que comienza a materializarse poco a poco a través de prototipos más o menos conocidos por los productores. Esto termina traduciéndose en una gran libertad por parte de la jurisprudencia para decidir si era razonable exigirle al fabricante del producto dañoso, en ese momento histórico determinado, la implementación de la nueva tecnología ${ }^{47}$.

45 "Junto con el otorgamiento de concesiones expresas de discrecionalidad que dan a los jueces facultades para desarrollar el Derecho, la vaguedad es una de las fuentes más importantes de discrecionalidad judicial". ENDICOTT (2007), p. 23.

${ }^{46}$ Esta precisión de la definición fue incluida por el derecho francés (art. 1386-4 C.C.), belga (art. 5 L. 25 de febrero de 1991), español (art. 3 núm. 3 L. 22/1994) e italiano (art. 5 núm. 2 DPR 24 de mayo de 1988, No 224).

${ }^{47}$ Véase: Coleman (2010), pp. 409-412. 
"El riesgo de desarrollo en la responsabilidad por productos del derecho colombiano"

Finalmente, el Estatuto del Consumidor colombiano, en su artículo 1948, consagra una especie de obligación de seguimiento del producto, haciendo eco a lo dispuesto por el artículo 5.1 de la Directiva 2001/95/CE del Parlamento Europeo y del Consejo de 3 de diciembre de 2001 (relativa a la seguridad general de los productos $)^{49}$ y pone en cabeza del productor una obligación adicional de seguimiento de los eventuales defectos que puedan manifestarse en los productos ${ }^{50}$.

${ }^{48}$ L. 1480/2011: artículo 19. "Deber de información. Cuando un miembro de la cadena de producción, distribución y comercialización, tenga conocimiento de que al menos un producto fabricado, importado o comercializado por él, tiene un defecto que ha producido o puede producir un evento adverso que atente contra la salud, la vida o la seguridad de las personas, deberá tomar las medidas correctivas frente a los productos no despachados y los puestos en circulación, y deberá informar el hecho dentro de los tres (3) días calendario siguientes a la autoridad que determine el Gobierno Nacional.

Parágrafo. Sin perjuicio de las responsabilidades administrativas individuales que se establezcan sobre el particular, en caso que el obligado no cumpla con lo previsto en este artículo, será responsable solidariamente con el productor por los daños que se deriven del incumplimiento de esa obligación".

${ }^{49}$ D.2001/95/CE, art. 5.1.: "Dentro de los límites de sus respectivas actividades, los productores proporcionarán a los consumidores información adecuada que les permita evaluar los riesgos inherentes a un producto durante su período de utilización normal o razonablemente previsible, cuando éstos no sean inmediatamente perceptibles sin avisos adecuados, a fin de que puedan precaverse de dichos riesgos. La existencia de tales avisos no eximirá del respeto de las demás obligaciones establecidas en la presente Directiva. Igualmente dentro de los límites de sus respectivas actividades, los productores adoptarán medidas apropiadas, según las características de los productos que suministren, de manera que puedan:

a) mantenerse informados de los riesgos que dichos productos puedan presentar;

b) actuar en consecuencia, si fuera necesario, retirando del mercado el producto para evitar dichos riesgos, avisando de manera adecuada y eficaz a los consumidores, o recuperando los productos de los consumidores.

Las medidas contempladas en el párrafo tercero incluirán por ejemplo:

a) la indicación, por medio del producto o de su embalaje, de la identidad y datos del productor y de la referencia del producto o, si procede, del lote de productos a que pertenezca, salvo en los casos en que la omisión de dicha indicación esté justificada; y

b) en todos los casos en que sea apropiado, la realización de pruebas por muestreo de los productos comercializados, el estudio y, si procede, el registro de las reclamaciones presentadas y la información del productor a los distribuidores sobre el seguimiento de estos productos.

Las acciones a que se refiere la letra b) del tercer párrafo se emprenderán voluntariamente o a instancia de las autoridades competentes de conformidad con la letra f) del apartado 1 del artículo 8. La recuperación tendrá lugar como último recurso cuando otras acciones no basten para prevenir los riesgos, cuando los productores lo estimen necesario o cuando se vean obligados a hacerlo a raíz de una medida adoptada por la autoridad competente. Podrá efectuarse en el marco de los códigos de buena conducta en la materia del Estado miembro afectado, cuando éstos existan".

${ }^{50}$ La Corte de Casación francesa, en 1967, ya había dispuesto que el fabricante de botellas de gas que no había tomado las medidas necesarias para verificar los defectos de las llaves de las botellas para, efectivamente, retirarlas del mercado, era responsable por los daños causados por ellas. Véase: Cour de Cassation. 2 civ. 12 avril 1967, D., 1967, somm. p. 106.

El 17 de marzo de 1981, la Bundesgerichtshof alemana, en el caso Benomyl Urteil, precisó que la obligación de información del productor se extiende más allá de la puesta en circulación de los productos. Consúltese al respecto: BORGHeTtı (2004), p. 6. 
Después de haber precisado lo que entendemos por "defecto" procederemos a analizar la siguiente expresión: "exoneración de responsabilidad".

\section{II}

La Directiva Europea en su artículo $7^{\circ}$ establece las hipótesis en las cuales "el productor no será responsable", a pesar de que la víctima haya probado el defecto del producto: (a) si no puso el producto en circulación; (b) si el defecto apareció después de la puesta en circulación; (c) si el producto no fue fabricado para ser distribuido en el ámbito de la actividad profesional del productor; (d) si el defecto se debe al cumplimiento de normas imperativas dictadas por los poderes públicos; (e) si se presentó un riesgo de desarrollo o (f) si, en el caso del fabricante de una parte integrante, el defecto es imputable al diseño del producto al cual se ha incorporado o a las instrucciones dadas por el fabricante de este producto.

Adicionalmente, el artículo $8^{\circ}$ establece que cuando el daño es causado conjuntamente por el producto defectuoso y el hecho de un tercero, la víctima puede demandar la totalidad de la indemnización al productor, sin perjuicio de las disposiciones de derecho interno de los Estados relativas al derecho a repetir (1), y la exoneración o reducción de la responsabilidad del productor cuando el daño se produjo conjuntamente por el hecho del producto defectuoso y la culpa de la víctima (2).

Sin embargo, a partir del momento en que la Directiva exige la prueba del vínculo causal entre el producto defectuoso puesto en circulación por el productor y el daño, la doctrina más representativa considera que el productor puede, en principio, exonerarse de responsabilidad probando la causa extraña, en los términos del derecho interno ${ }^{51}$.

En Colombia, el Estatuto del Consumidor incluyó en una sola disposición la causa extraña del derecho común -fuerza mayor o caso fortuito, hecho de un tercero y hecho de la víctima- y las particularidades del régimen especial de responsabilidad por productos defectuosos:

"Artículo 22. Exoneración de responsabilidad por daños por producto defectuoso. Solo son admisibles como causales de exoneración de la responsabilidad por daños por producto defectuoso las siguientes:

1. Por fuerza mayor o caso fortuito;

2. Cuando los daños ocurran por culpa exclusiva del afectado;

3. Por hecho de un tercero;

4. Cuando no haya puesto el producto en circulación;

51 Véase: Larroumet (1998 a), p. 316; Viney (1998), p. 295. 
5. Cuando el defecto es consecuencia directa de la elaboración, rotulación o empaquetamiento del producto conforme a normas imperativas existentes, sin que el defecto pudiera ser evitado por el productor sin violar dicha norma;

6. Cuando en el momento en que el producto fue puesto en circulación, el estado de los conocimientos científicos y técnicos no permitía descubrir la existencia del defecto. Lo anterior, sin perjuicio de lo establecido en el artículo 19 de la presente ley.

Parágrafo. Cuando haya concurrencia de causas en la producción del daño, la responsabilidad del productor podrá disminuirse.

Sin embargo, la redacción de esta disposición no se ajusta exactamente a lo dispuesto en el Código Civil colombiano respecto de la causa extraña ${ }^{52}$. En efecto, la norma no hace referencia a la solidaridad entre los distintos causantes del daño (art. 2344 C.C.col., art. 2317 C.C.ch., art. 8-1 D. 374/1985) y, además, parece exigir la culpa en el comportamiento de la víctima, para la exoneración total, y no sólo para la reducción -exoneración parcial- (art. 2357 C.C.col., art. 2330 C.C.ch. $)^{53}$.

Ahora bien, el análisis de esta disposición en su conjunto excede los objetivos que perseguimos con este ensayo. Por tal razón, nos limitaremos a estudiar el significado de la expresión "exoneración de responsabilidad" con relación al riesgo de desarrollo.

En el derecho colombiano, se suelen designar los medios de defensa del demandado en el proceso de responsabilidad civil mediante dos expresiones: "causales de exoneración de responsabilidad", para la fuerza mayor o caso fortuito, el hecho de un tercero y el hecho de la víctima -conocidos, en conjunto, como "causa extraña"-, y "causales de justificación de responsabilidad", para la legítima defensa, el estado de necesidad y la orden de autoridad o de la ley ${ }^{54}$.

\footnotetext{
${ }^{52}$ El Código de don Andrés Bello fue adoptado sin modificaciones sustanciales por el legislador colombiano en 1873 y, hoy en día, las disposiciones concernientes a las obligaciones y los contratos no han sufrido ningún cambio sustancial, por lo menos, en lo que respecta a la letra de los textos.

${ }^{53}$ Un análisis claro y preciso sobre la justificación de la mencionada solidaridad y de la exigencia del mero hecho de la víctima, en caso de exoneración total, y del hecho culposo, para la exoneración parcial, en: BénAC-SChmidt y LaRroumet (1989), pp. 38-44 y BACAChe-Gibelli (2007), pp. 454-491. Véase también a: LARROUMET (2000), pp. 1592-1593.

${ }^{54}$ Véase, a título de ejemplo: Tamayo (2007), pp. 1-160; Díaz-Granados (2012 a), pp. 64-68; Barrera y SANTOS (2003).

Dentro de las causales de justificación de responsabilidad -denominadas también, circunstancias que permiten justificar la trasgresión de una norma jurídica obligatoria- , parte de la doctrina incluye también el consentimiento de la víctima y la aceptación de los riesgos. Véase: VINEY y JOURDAIN (2006), pp. 583-593.
} 
Pero, ¿es el riesgo de desarrollo una verdadera causal de exoneración de responsabilidad? Dicho de otra manera, ¿es el riesgo de desarrollo una causa extraña? O, mejor aún, ¿es el riesgo de desarrollo un hecho imprevisible, irresistible y externo que desvirtúa el vínculo causal entre el producto defectuoso puesto en circulación por el productor y el daño sufrido por la víctima?

En principio, se podría creer que sí: en el momento de la puesta en circulación del producto, el productor no podía conocer el defecto y, por ende, le resultaba imposible evitar su presencia y sus consecuencias dañosas -salvo en caso de incumplimiento de la obligación de seguimiento del producto-.

$\mathrm{Si}$, con la doctrina predominante, se acepta que la irresistibilidad es el elemento definitorio de la causa extraña y la imprevisibilidad y exterioridad son sólo contingentes ${ }^{55}$, el riesgo de desarrollo parecería un ejemplo más de fuerza mayor: "La fuerza mayor, cualquiera que sea campo de aplicación, exige que el acontecimiento perturbador, inevitable e irresistible, ponga al sujeto en una situación de imposibilidad" 56 .

Empero, como bien lo precisa el profesor Larroumet, "lo característico de la causa extraña es la destrucción del vínculo causal entre un hecho que se supone dañoso y el acaecimiento del daño. En otras palabras, la prueba de una causa extraña tiene por efecto demostrar que el hecho que se podría creer [sic] origen del daño, en realidad, no fue la causa de éste. Pero esto no se produce con la demostración de un riesgo de desarrollo" ${ }^{\prime 57}$.

En efecto, el producto es defectuoso por el simple hecho de no ofrecer la razonable seguridad a la que toda persona tiene derecho y el Estatuto del Consumidor colombiano no duda en calificar de defectuoso al producto cuyos problemas de seguridad sólo se descubrieron posteriormente, por los avances de la ciencia y la tecnología. Por consiguiente, si los daños fueron causados por este problema de seguridad, el vínculo causal está plenamente establecido. En el defecto del producto se halla, entonces, el origen del daño. Antes de la Ley $N^{\circ} 1480$ de 2011, el lenguaje de los contratos del derecho colombiano llamaría a esto, simple y llanamente, un vicio oculto ${ }^{58}$.

Si el productor no responde a pesar de que el producto defectuoso que puso en circulación causó el daño, ¿a qué corresponde esta "causal de exoneración" por riesgo de desarrollo? Algunos doctrinantes se inclinan por hacerla entrar en la categoría de la causa extraña ${ }^{59}$; pero, ¿cómo explicar

\footnotetext{
${ }^{55}$ Consúltese al respecto: Larroumet (2007), pp. 293-317.

${ }^{56}$ Antonmattel (1992), p. 66.

${ }^{57}$ LaRroumet (2000), pp. 1589-1598.

${ }^{58}$ Consúltese al respecto: Mantilla (2010), pp. 523-553 y Mantilla (2013), pp. 93-118.

${ }^{59}$ Véase: Viney (1998), pp. 295-297 y Testu y Moitry (1998), pp. 13-14.
} 
una causa extraña que no pretende romper el vínculo causal?, ¿cómo definir una causa extraña que no corresponde a la definición de la causa extraña? Esto nos recuerda el famoso cuchillo sin hoja al que le falta el mango, del célebre filósofo alemán ${ }^{60}$.

Además, si se aceptase que el riesgo de desarrollo es sólo una causa extraña, tendría que modificarse el significado de la expresión genérica "causa extraña", lo cual podría traer como consecuencia que el riesgo de desarrollo, como causa extraña, terminara extendiéndose a otros ámbitos distintos de la responsabilidad por productos defectuosos ${ }^{61}$.

Otros autores tratan de explicarlo como una suerte de caso exceptuado ${ }^{62}$, es decir, una hipótesis contemplada por la ley en la cual el demandado no es responsable, a pesar de cumplirse con las condiciones de su responsabilidad y sin que se haya logrado romper el vínculo causal -esto, en últimas, podría corresponder a una causal de justificación-.

Pero, ipor qué, entonces, la solución nos parece tan sensata, tan evidente, tan familiar?, ¿por qué la novedad del riesgo de desarrollo no nos sorprende ni desconcierta? Tal vez la respuesta radique en el hecho de que "riesgo de desarrollo" sólo sea una expresión especial usada para designar una vieja institución a la cual nos encontramos habituados.

De acuerdo con el fallo de 29 de mayo de 1997 del Tribunal de Justicia de la Unión Europea, el productor debe demostrar que, para el momento de la puesta en circulación del producto, el estado de la ciencia y la tecnología más avanzado y accesible no le permitía descubrir el defecto. En otras palabras, el productor se exonera de responsabilidad si logra demostrar que el productor conocedor de la ciencia y tecnología, sujeto abstracto, hubiera actuado igual que él, en las mismas circunstancias.

Esto es, claramente, un juicio de valor respecto de una conducta concreta, llevado a cabo de acuerdo con unos parámetros sociales específicos: si el productor no se comportó como un profesional avisado y muy bien informado, debe indemnizar los daños. Si, por el contrario, fue diligente y prudente en la utilización de la tecnología más avanzada conocida para garantizar la seguridad de sus productos, pero, aun así, no le fue posible evitar el defecto, el sistema le permite exonerarse alegando un riesgo de desarrollo ${ }^{63}$. Así las cosas, no nos

60 "El cuchillo sin hoja, al que le falta el mango" fue el título utilizado por Lichtenberg para el Capítulo VIII de sus célebres aforismos. Véase: LICHTENBERG (1995), p. 227.

${ }^{61}$ Un análisis al respecto en: LaRroumet (2000), pp. 1589-1601.

${ }^{62}$ Larroumet (2000).

63 "Los juicios de valor, cualquiera que sea su naturaleza, implican alguna clase de aprobación o desaprobación. Pero los términos valorativos pueden ser usados descriptivamente en enunciados que 
resta más que aceptar que estamos ante una exoneración por la prueba de la ausencia de culpa ${ }^{64}$.

Pero esta conclusión no debe sorprendernos. En efecto, la jurisprudencia actual en los Estados Unidos de Norteamérica parece aceptar, de manera estable, que la responsabilidad por defectos de productos que el estado de la ciencia y la tecnología ${ }^{65}$, en el momento de su puesta en el mercado, no permitían al productor descubrirlos está fundamentada en la negligence y sólo respondería en la hipótesis en que, para el momento, hubiera existido una Reasonable alternative design ${ }^{66}-\mathrm{RAD}^{67}$.

no expresan valoraciones (aprobación o desaprobación), sino proposiciones fácticas, es decir, proposiciones a los efectos de que la cosa en cuestión satisface las pautas o criterios valorativos de una cierta comunidad o grupo social". AlChOURRÓn y BULYGIN (1991), p. 315.

${ }^{64}$ Sobre los juicios comparativos valorativos, como el que conlleva el análisis de la culpa, véase: Mantilla y Pizarro (2011), pp. 331-380 y Mantilla y Ternera (2006), pp. 125-137.

${ }^{65}$ Ahora bien, la referencia al "State of the Art" no se explica como una causal de exoneración de responsabilidad, sino como un criterio para definir cuándo un producto tiene un "defecto de diseño". Así y todo, en nuestra opinión, esta distinción no parece de gran importancia puesto que decir que un producto no es defectuoso porque se elaboró conforme a las reglas del arte es, a la larga, lo mismo que decir que el productor se exonera de la responsabilidad derivada de los daños causados por sus productos si prueba que se elaboraron siguiendo las reglas del arte. Es más, la doctrina misma se refiere al "State of the Art" como una "defensa". Consúltese: EpSTEIN (1999), p. 411.

${ }^{66}$ Véase un fallo paradigmático en: Court of Appeals. Osorio v. One World Technologies, Inc., 659 F.3d 81 (1st Cir. 2011). Disponible en: http://lawyersusaonline.com/wp-files/pdfs-3/osario-v-one-worldtechnologies.pdf. [visitado el 18/06/2013].

Se trata del accidente del ciudadano colombiano Carlos Osorio, quien sufrió severos traumatismos en su mano por la manipulación de una sierra Ryobi Modelo BTS15. Para el caso concreto, el jurado estimó negligencias o culpas concurrentes tanto del actor-Osorio-como del demandado-One World Technologies, Inc.-: la maniobra del artefacto y el funcionamiento mismo de la máquina adolecieron de duros problemas. Respecto del demandado, se estimó que no se trataba de un reasonable alternative design, sino de un "unreasonable alternative design". Por lo demás, en el texto se cita una nutrida jurisprudencia. Véase, por ejemplo, a: Morales-Vallellanes v. Potter, 605 F.3d 27, 33 (1st Cir. 2010); Granfield v. CSXTransp., Inc., 597 F.3d 474, 482 (1st Cir. 2010); Cigna Ins. Co. v. Oy Saunatec, Ltd., 241 F.3d 1, 8 (1 st Cir. 2001), etc.

${ }^{67}$ Sobre la evolución del derecho norteamericano en este punto, véase a: MEADE (2010).

En la doctrina se pueden ver voces que advierten del cambio de tratamiento entre el Restatement (Second) y el Restatement (Third): "el Restatement (Second) fue promulgado en los años sesenta, respecto de fabricantes que resultaban responsables según los parámetros de la responsabilidad objetiva -strict liability in tort-. Ahora bien, desde su promulgación, muchos tribunales se percataron de los inconvenientes de la aplicación de la responsabilidad objetiva como remedio apropiado y total, especialmente en las hipótesis en las cuales el fabricante actuó de manera razonable cuando puso el producto en el mercado". Stevens, Robert, "The Restatement (Third) of Products Liability: Is It a Reasonable Alternative Design to Tennessee's Products Liability Statute?", University of Memphis Law Review, Vol. 39 2, January 2009, p. 2.

Véase también a: Borghettı (2004), pp. 48-68., y Coleman (2010), pp. 409-412.

Respecto de la aplicación de test para determinar la negligence, consúltese: MOORE (2011), pp. 247-293. 
Es más, el famoso fallo alemán de 26 de noviembre de 1968, conocido como Hühnerpest y mencionado varias veces en este ensayo, estableció que el productor que lograba probar que el estado de la ciencia y la tecnología no le permitía descubrir el defecto, demostraba su ausencia de culpa y, por ende, no podía ser condenado con base en el $\S 823$ del BGB ${ }^{68}$.

$\mathrm{Si}$ entendemos que el riesgo de desarrollo no es más que una forma especial de probar en contra de una presunción de culpa que pesa sobre el productor, resultará mucho más coherente la obligación de seguimiento del producto (D.2001/95/CE, art. 5.1 y L.1480/2011, art. 19) que permite comprometer la responsabilidad del productor, y de los otros miembros de la cadena de distribución, cuando se les puede imputar culpa respecto de las medidas que toman para evitar daños que puedan causarse por eventuales defectos que se manifiesten en los productos puestos en circulación -obligación de medios- ${ }^{69}$.

A esta misma conclusión ha llegado parte de la doctrina. Como bien lo precisa el profesor Borghetti: "junto a ciertos autores, somos de la opinión de que la exoneración por riesgo de desarrollo prevista por la Directiva equivale a una exoneración por ausencia de culpa y de que la interpretación hecha por el Tribunal de Justicia del artículo 7.E [TJUE, fallo de 29 de mayo de 1997] no ha, en lo absoluto, cambiado esta situación; muy por el contrario, la ha confirmado. Conviene, sin embargo, no sacar conclusiones alarmistas de esta constatación, incluso si se es un radical opositor a esta causal de exoneración. En principio, incluso si el productor pudiera escapar a su responsabilidad mediante la prueba de que, legítimamente, podía ignorar la existencia del riesgo que se concretó, la medida exacta de la exoneración dependerá del grado de exigencia adoptado por los jueces" ${ }^{\prime 70}$.

Un interesante análisis sobre la coexistencia de la negligence y la strict liability en Estados Unidos e Inglaterra, en: GUERRA (2012), pp. 565-583.

${ }^{68} \S 823$ del BGB: "Quien, actuando intencionalmente o por negligencia, atente de manera ilícita contra la vida, cuerpo, salud, libertad o propiedad o contra cualquier otro derecho de otra persona, está obligado para con ésta a reparar el daño que resulte de su actuación".

Es cierto que la ley alemana que adoptó la Directiva Europea (15 de diciembre de 1989) eliminó las referencias expresas a la culpa para esta hipótesis; sin embargo, buena parte de la doctrina considera que el cambio de las palabras "culpa" por "defecto" no introdujo ningún cambio sustancial. Véase al respecto: ANCEL (2012).

${ }^{69}$ Véase : Borghetti (2004), pp. 331-333 y Larroumet (2000), p. 1593.

${ }^{70}$ Véase : BorGhettı (2004), pp. 467-468.

Incluso el profesor Larroumet la había intuido ya, sin embargo, la idea preconcebida de que el régimen de responsabilidad por productos defectuosos debe ser un régimen objetivo, lo hizo desviar de su razonamiento. Véase a: LARROUMet (2000), pp. 1599-1601. 
Así las cosas, tenemos que concluir que si el régimen de responsabilidad por productos defectuosos en el derecho colombiano consagra una causal de exoneración por ausencia de culpa es, necesariamente, un régimen subjetivo de responsabilidad ${ }^{71}$; con presunción de culpa ${ }^{72}$ y con una limitación probatoria en cuanto a la ausencia de culpa -sólo se admite mediante prueba del riesgo de desarrollo-, pero subjetivo, al fin de cuentas $^{73}$.

Philippe Le Tourneau lo expresó con total claridad: "en los regímenes objetivos de responsabilidad todo conspira contra la eliminación radical de la culpa. Ésta, a la larga, termina aflorando para perturbar la fría coherencia de la que aquéllos hacen gala. Nos guste o no, esto es innegable. Hace algún tiempo escribí 'echad a la culpa y ésta regresará al galope'. Y esto es, precisamente, lo que está pasando"74.

Tal vez esto explique por qué la exoneración de responsabilidad mediante prueba del riesgo de desarrollo nos parece, de entrada, tan familiar, a pesar de que la expresión es completamente nueva en el derecho colombiano.

"Que se deba pagar una indemnización por el daño causado a otro por su actuación culposa parece una exigencia fundamental de la justicia: opera enim illorum sequuntur illos. Esta idea está igualmente relacionada con la idea del castigo, la cual se halla anclada en lo más profundo de nuestras mentes. El recuerdo del fruto prohibido, escribía Bergson, es quizás lo más antiguo que se encuentra tanto en la memoria de cada uno de nosotros, como en la memoria de la humanidad misma"75.

\footnotetext{
${ }^{71}$ Parte de la doctrina colombiana afirma sin ambages que la responsabilidad por productos defectuosos es objetiva, sólo por el hecho de que la palabra "culpa" no aparece en ninguno de los numerales del artículo 22 de la Ley № 1480 de 2011. Véase: Díaz-Granados (2012 a), pp. 317-324.

Finalmente, una autora sostiene que por la aceptación del riesgo de desarrollo en la Directiva Europea, la culpa "filtra el esquema de la responsabilidad objetiva del productor", pero que "no constituye su criterio de imputación ni su fundamento". Afirmación muy interesante, pero su significado resulta realmente enigmático. Véase: Woolcotr (2007), pp. 495-505.

72 "Hay que precisar que, como la existencia de un riesgo de desarrollo debe ser probada por el productor, estaríamos en presencia de un régimen de responsabilidad por culpa, pero, con inversión de la carga de la prueba y no de una responsabilidad por culpa pura y simple". BorghetTI (2004), p. 192.

${ }^{73}$ Se dice que la responsabilidad es subjetiva cuando la norma que condena a indemnizar los daños (sanción) exige la culpa (supuesto de hecho) y objetiva cuando no la exige. Vemos, entonces, que estos adjetivos sirven para calificar las normas -como creaciones intelectuales-y no los hechos del mundo -como entidades que se perciben por los sentidos- y se refieren a sus condiciones de aplicación. No sobra precisar que tanto "subjetivo" como "objetivo" califican la conducta del sujeto normativo -el agente- y no el vínculo causal ni el daño.

${ }^{74}$ Le Tourneau (1988), p. 512. Consúltese también: Piaggio (2005).

75 TUNC (1989), p. 98.
} 
Los regímenes de responsabilidad por productos defectuosos fueron creados, básicamente, para trascender las fronteras de los contratos que instrumentan las redes de distribución. En este orden de ideas, la totalidad de los daños causados por los productos es sometida a un mismo régimen de responsabilidad -unificación de la reparación entre contratantes y terceros-, la distribución de riesgos y costos de los accidentes se sustrae de la esfera negocial y se remite a regulación general imperativa que los pone, en buena medida, en cabeza de los productores, quienes, en principio, deberían "socializarlos" mediante la contratación de pólizas de seguro, cuyo costo repercutiría en los precios de los productos que todos adquirimos cotidianamente ${ }^{76}$.

Su confección es el resultado de un compromiso entre dos suertes de intereses contrapuestos y no siempre fáciles de conciliar: los de los productores y los de los consumidores. Éstos demandan mayor cobertura para los riesgos que implican los productos cada vez más sofisticados de nuestra sociedad moderna y aquéllos requieren unas condiciones jurídicas idóneas para continuar con la producción y la innovación de forma segura y rentable ${ }^{77}$.

El Estatuto del Consumidor del derecho colombiano (L.1480/2011) trató de conseguir este equilibrio, concediendo a los consumidores unas acciones para la indemnización de daños que pueden ejercerse contra todos los proveedores de la cadena de distribución, pero, para beneficio de los productores, los limita sólo para dos clases de perjuicios: los corporales y los sufridos por una cosa diferente del producto defectuoso (arts. 19 y 20).

La exoneración en caso de que el estado de la ciencia y la tecnología, en el momento de la puesta en el mercado de los productos, no hubiera permitido descubrir el defecto es un beneficio para los productores muy especial: no es nada distinto de la admisión de una hipótesis de exoneración mediante prueba de la ausencia de culpa encubierta por una expresión tan glamurosa como enigmática, "el riesgo de desarrollo".

\footnotetext{
${ }^{76}$ Un análisis trasversal desde la perspectiva del derecho privado clásico en: LARROUMET (1998 b), pp. 3-7; y un interesante estudio desde la óptica del análisis económico del derecho en: Coleman (2010), pp. 405-425.

77 "Respecto del seguro, los problemas de selección adversa y de riesgo moral pueden ser explicados mediante ejemplos. El riesgo moral es el efecto que produce la existencia del seguro sobre el nivel de los reclamos que se realizan con base en el seguro. El riesgo moral ex ante es el fenómeno de la disminución de las precauciones dada simplemente la existencia del seguro. El riesgo moral ex post es el fenómeno de los reclamos luego del hecho y, [...], es en parte una función de quien paga. El problema de la selección adversa es una función de las fluctuaciones en la expectativa de riesgo entre los miembros de un fondo de asegurados. A medida que la fluctuación se hace demasiado grande, los miembros de bajo riesgo ya no encuentran atractivo el seguro y se retiran, dejando sólo a los miembros de alto riesgo, lo que a su vez hace poco atractivo para la compañía brindar un seguro contra esos riesgos". Coleman (2010), p. 412.
} 
En efecto, antes de la adopción de los regímenes de responsabilidad por el hecho de los productos, los daños que éstos causaban estaban, en buena medida, regulados por un régimen de garantía, por vicios ocultos, o, incluso, por obligaciones de seguridad de resultado -generalmente, de origen jurisprudencial-que se traducían en regímenes objetivos de responsabilidad ${ }^{78}$. ¿Cómo pasar, entonces, a la admisión de una hipótesis de exoneración por ausencia de culpa? ¿cómo apaciguar la presión de los consumidores? La respuesta fue tan sencilla como eficaz: admitiéndola, pero con otro nombre.

Si repasamos la historia de la negociación de la Directiva Europea 374 de 1985 podremos corroborar que su inclusión se hizo bajo presión de la delegación alemana -país cuya jurisprudencia la había aceptado desde el fallo Hühnerpest-, pero, ante la férrea oposición de otros países, la Directiva optó por una solución intermedia, permitiendo a cada Estado adoptarla o no, mediante sus leyes introductorias ${ }^{79}$.

A pesar de esto, la inmensa mayoría de los miembros de la Unión terminaron admitiéndola por razones económicas. En efecto, de no hacerlo, las empresas de los países que no aceptan la exoneración estarían en desventaja competitiva, frente a las empresas de los países que la aceptan ${ }^{80}$. Sin embargo, las particularidades de la institución en cada país obedecen a sus presiones políticas y sociales internas; por ejemplo, Alemania la acepta, con exclusión de los daños causados por medicamentos - no hay que olvidar que, a finales de la década de 1960, en este país el medicamento Contergan (Talidomida) produjo malformaciones en cerca de 2.500 recién nacidos ${ }^{81}$; España la incluyó para todos los productos excepto para los medicamentos y los productos alimenticios para el consumo humano -aparte de los problemas de la Talidomida, en este país, a principios de la década de 1980, se presentó una intoxicación de más de 15.000 personas por consumo del aceite de colza, también conocido como aceite de canola-82; Francia, por su parte, la admitió para todos los productos, salvo los derivados del cuerpo humano -recordemos que, entre finales de la década de 1980 y la década de 1990, allí se presentaron graves escándalos por contagios con hepatitis B y SIDA, como consecuencia de transfusiones con sangre contaminada- ${ }^{83}$.

\footnotetext{
${ }^{78}$ Consúltese: Larroumet (1998 b), pp. 3-7.

${ }^{79}$ Véase a: VINEY (1998), p. 296.

${ }^{80}$ Consúltese: Leveneur (1998), pp. 31-32 y Márquez y Moisset de Espanés (2009), pp. 770-777.

${ }^{81}$ Consúltese al respecto: Borghettı (2004), p. 7.

${ }^{82}$ Véase: GonZÁlez (2005), pp. 109-143.

${ }^{83}$ Véase: Mémeteau (2006), pp. 525-532.
} 
Vemos cómo la responsabilidad por productos defectuosos y la exoneración por riesgo de desarrollo reflejan perfectamente el fenómeno actual de repartición de riesgos al interior de la sociedad y nos muestran cómo las instituciones jurídicas terminan adaptándose, de forma más o menos abierta, a las presiones económicas, políticas y sociales ${ }^{84}$, tal y como lo precisó Ulrich Beck hace ya cerca de treinta años:

"En la modernidad avanzada, la producción social de riqueza va acompañada sistemáticamente por la producción social de riesgos. Por tanto, los problemas y conflictos de reparto de la sociedad de la carencia son sustituidos por los problemas y conflictos que surgen de la producción, definición y reparto de los riesgos producidos de manera científico-técnica" ${ }^{85}$.

\section{Bibliografía CitADA}

Alchourrón, Carlos y Bulygin, Eugenio (1991): "Los límites de la lógica y el razonamiento jurídico", en: Alchourrón, Carlos y Bulygin, Eugenio, Análisis lógico y derecho (Madrid, Ed. Centro de Estudios Constitucionales), pp. 303-328.

Atpa, Guido (2006): Nuevo tratado de la responsabilidad civil (Traducc. Leysser León, Lima, Jurista).

AnCEL, Pascal (2012): Les dommages réparables et l'étendue de la réparation (Rapport allemand). Disponible en: http://grerca.univ-rennes1.fr/ digitalAssets/304/304968_17-pancel.pdf [visitado el 24/05/2013].

ANNICCHIARICO, José (2008): “La obligación de seguridad y la ley de protección al consumidor y al usuario venezolana. Ensayo de una responsabilidad legal del proveedor", en: Estudios de derecho privado en homenaje a Christian Larroumet (Santiago de Chile, Ed. Fundación Fernando Fueyo Laneri/Universidad Diego Portales/Universidad del Rosario), pp. 47-65.

Antonmattel, Paul-Henri (1992): Contribution à l'étude de la force majeure (Paris, LGDJ), p. 66.

Bacache-Gibeilı, Mireille (2007): Droit civil. Tome V, Les obligations. La responsabilité civile extracontractuelle (Paris, Ed. Economica).

Barrera Tapias, Carlos Darío y Santos Ballesteros, Jorge (2003): El daño justificado (Bogotá, Pontificia Universidad Javeriana).

Barría Díaz, Rodrigo (2011): "El daño causado por el miembro indeterminado de un grupo y su posible recepción en el derecho chileno", en: Revista de Derecho Escuela de Postgrado ( $^{\circ} 1$ ), pp. 151-183. Disponible en: http://

${ }^{84}$ Véase : Larroumet (1998 a), p. 315 y Larroumet (2000), pp. 1599-1601.

${ }^{85}$ BECK (2009), p. 29. 
www.revistas.uchile.cl/index.php/RDEP/article/viewFile/22788/24174 [visitado el 20/05/2013].

Barros Bourie, Enrique (2007): Tratado de responsabilidad extracontractual (Santiago, Editorial Jurídica de Chile).

BLACK, Max (1984): Inducción y probabilidad (Traducc. Rafael Beneyto, Madrid, Cátedra).

BénaC-SChmidt, Françoise y LaRroumet, Christian (1989): "Responsabilité du fait des choses inanimées", en : Recueil Dalloz Encyclopédique (Paris, Dalloz), pp. 25-52.

BECK, Ulrich (2006): La sociedad del riesgo. Hacia una nueva modernidad (Traducc. Jorge Navarro et al., Barcelona, Paidós).

BECK, Ulrich (2009): La sociedad del riesgo global (Traducc. Jesús Alborés Rey, Madrid, Siglo XXI).

BerG, Olivier (1996): "La notion de risque de développement en matière de responsabilité du fait des produits défectueux", en: La semaine juridique (No 27, 2945).

BORGHETTI, Jean-Sébastien (2004): La responsabilité du fait des produits. Étude de droit comparé (Paris, LGDJ).

Bullard González, Alfredo (2006): Derecho y economía, Análisis económico de las instituciones legales (Lima, Palestra).

CAPRILE BiermanN, Bruno (2008): "Las acciones del acreedor insatisfecho: el cúmulo actual (ley de protección al consumidor, vicios redhibitorios, error substancial, resolución por incumplimiento) y la tendencia al deber de conformidad (Convención de Viena de 1980 sobre compraventa internacional de mercaderías y Directiva Europea 1999/44/CE)", en: Estudios de derecho privado en homenaje a Christian Larroumet (Santiago de Chile, Ed. Fundación Fernando Fueyo Laneri/Universidad Diego Portales/Universidad del Rosario), pp. 561-602.

CARrió, Genaro (1994): Notas sobre derecho y lenguaje (Buenos Aires, Abeledo-Perrot).

Carrió, Genaro (1962): Prefacio a Hart, Herbert L. A, Derecho y moral. Contribuciones a su análisis (Traducc. Genaro Carrió, Buenos Aires, Depalma).

COOTER, Robert y ULen, Thomas (1999): Derecho y economía (Trad. Eduardo Suárez, México, Fondo de cultura económica).

Deakin, Simon; Johnston, Angus y Markesinis, Basil (2003): Tort Law (Oxford, Oxford University Press).

Díaz-Granados Ortiz, Juan Manuel (2012 a): El seguro de responsabilidad civil, Universidad del Rosario/Pontificia Universidad Javeriana, Bogotá, 2012.

Díaz-Granados Ortiz, Juan Manuel (2012 b): "El Nuevo estatuto del consumidor en Colombia. Su incidencia en el contrato de seguro", en: Revista Ibero-La- 
tinoamericana de Seguros (№ 36), pp. 59-96. En: http://www.fasecolda.com/ fasecolda/BancoMedios/Documentos\%20PDF/004-estatutoconsumidor.pdf [visitado el 07/10/2012].

Dízz-PICAzo, Luis (2011): Fundamentos del derecho civil patrimonial, La responsabilidad civil extracontractual (Madrid, Thomson Reuters/Civitas).

ENDicotT, Timothy (2007): La vaguedad en el derecho (Traducc. Alberto del Real Alcalá y Juan Vega Gómez, Madrid, Dykinson).

Epsteln, Richard Allen (1999): Torts (Nueva York, Aspen Publishers).

Giraldo López, Alejandro; Caycedo Espinel, Carlos Germán y Madriñán Rivera, Ramón Eduardo (2012): Comentarios al nuevo estatuto del consumidor. Ley No 1480 de 2011 (Bogotá, Legis).

Gometz, Gianmarco (2012): La certeza jurídica como previsibilidad (Traducc. Diego Moreno Cruz y Diego Dei Vecchi, Madrid, Marcial Pons).

González LaGier, Daniel (2005): Quaestio Facti. Ensayos sobre prueba, causalidad y acción (Lima/Bogotá, Palestra/Temis).

Guerra Hernández, Víctor Hugo (2012): “¿Cómo sobrevive en Venezuela la empresa privada al Ilamado socialismo del siglo XXI?", en: Libro homenaje al profesor Alfredo Morales Hernández. Temas generales de derecho mercantil, Volumen I (Caracas, Ed. Universidad Católica Andrés Bello), pp. 565-583.

Guerra Hernández, Víctor Hugo (2002): La responsabilidad civil extracontractual por productos en el derecho internacional privado, Estudio comparado (Caracas, UCAB).

HARE, Richard Mervyn (1975): El lenguaje de la moral (Traducc. Genaro Carrió y Eduardo Rabossi, México, UNAM).

LARroumet, Christian (1998 a) : La responsabilité du fait des produits défectueux après la loi du 19 mai 1998, en: Recueil Dalloz, Chronique, Cahier 33.

Larroumet, Christian (1998 b): Introduction. Petites affiches. La loi, No 155, La responsabilité du fait des produits défectueux (loi du 19 mai 1998).

LARROUMET, Christian (2000): "La notion de développement, risque du XXI siècle", en :Clés pour le siècle. Droit et science politique, information et communication, sciences économiques et de gestion (Paris, Université Panthéon-Assas (Paris II), Dalloz).

Larroumet, Christian (2007): "La causa extraña", en: Los contratos en el derecho privado (Bogotá, Ed. Legis/Universidad del Rosario), pp. 293-317.

Le Tourneau, Philippe (1988): "La verdeur de la faute dans la responsabilité civile (ou la relativité de son déclin)", en: RTD civ. 87 (3), pp. 505-518.

LeVENEUR, Laurent (2002): Droit des contrats. 10 ans de jurisprudence commentée. La pratique en 400 décisions (Paris, Litec). 
Leveneur, Laurent (1998): "Le défaut", en: Petites affiches. La loi, No 155, La responsabilité du fait des produits défectueux (loi du 19 mai 1998), pp. 28-36. LiCHTENBERG, Georg Christoph (1995): Aforismos (Traducc. Juan Villoro, Santiago de Chile, Ed. Fondo de cultura económica).

MANTILLA ESPINOSA, Fabricio (2010): "Sobre las acciones del comprador insatisfecho", en: Realidades y tendencias del derecho en el siglo XXI. Derecho privado, tomo IV, 2. (Bogotá, Ed. Universidad Javeriana/Temis), pp. 523-553.

Mantilla Espinosa, Fabricio (2013): "La garantía de buen funcionamiento de la cosa vendida en el Código de Comercio colombiano", en: Revista Foro de Derecho Mercantil (№ 38), pp. 93-118.

Mantilla Espinosa, Fabricio y Ternera Barrios, Francisco (2006): "La 'culpa' en la responsabilidad civil extracontractual del derecho colombiano", en: Revista de responsabilidad civil y seguros. ( $\left.\mathrm{N}^{\circ} \mathrm{XII}\right)$, pp. 125-137.

Mantilla Espinosa, Fabricio y PIZARRO Wilson, Carlos (2011): "La responsabilidad civil por actividades peligrosas: aplique primero y explique después", en Maximiliano Aramburo Calle (coord.), en: Responsabilidad civil, derecho de seguros y filosofía del derecho, tomo I. Homenaje al profesor Javier Tamayo Jaramillo (Medellín, Ed. Diké), pp. 331-380.

Márquez, José Fernando y MoISSET de EsPanés, Luis (2009): "Responsabilidad por productos y servicios peligrosos o defectuosos. El riesgo de desarrollo como eximente", en: Ley de defensa del consumidor comentada y anotada, tomo II, pp. 770-777.

MARTIN, Anne-Cécile (2009): L'imputation des risques entre les contractants (Paris, LGDJ).

MezzAsoma, Lorenzo (2012): La responsabilidad por los daños causados por las cosas en el derecho contemporáneo, Especial referencia al derecho italiano y español (Bogotá, Ibáñez/Pontificia Universidad Javeriana/Università degli Studi di Perugia).

Meade, Andrew (2010): "A Reasonable Alternative to the Reasonable Alternative Design Requirement in Products Liability Law: A Look at Pennsylvania", en: Hastings Law Journal, pp. 155-183.

Mémeteau, Gérard (2006): Cours de droit médical (Bordeaux, Les études hospitalières).

MOORE, Michael (2011): Causalidad y responsabilidad, Un ensayo sobre derecho, moral y metafísica (Madrid, Marcial Pons).

NAKHNIKIAN, George (1998): El derecho y las teorías éticas contemporáneas (Traducc. Eugenio Bulygin y Genaro Carrió (México, Fontamara, Col. BÉFDP).

PiagGio, Aníbal (2005): "Presencias de la culpa", en: La ley, Responsabilidad Civil Doctrinas Esenciales, tomo II, pp. 207-223. 
PICAsSo, Sebastián y VÁzquez Ferreyra, Roberto (Direct.) (2009): Ley de defensa del consumidor comentada y anotada (Buenos Aires, La Ley), tomo I y tomo II.

RochfelD, Judith (2011): Les grandes notions du droit privé (París, Puf).

ROSENKRANTZ, Carlos (1998): "El riesgo y la responsabilidad extracontractual: algunas consideraciones filosóficas, jurídicas y económicas acerca de una difícil relación", en: Revista Jurídica de la Universidad de Palermo ( $\mathrm{N}^{\circ}$ 4), pp. 45-80. Disponible en: http://www.palermo.edu/derecho/publicaciones/pdfs/revista_juridica/n3N2-Octubre1998/032Juridica02.pdf [visitado el 20/05/2013].

RYLE, Gilbert (2005): El concepto de lo mental (Traducc. Eduardo Rabossi, Buenos Aires, Paidós).

Schopenhauer, Arthur (1991): Le fondement de la morale (Traducc. Auguste Burdeau, Paris, Le livre de poche).

Stevens, Robert (2009): "The Restatement (Third) of Products Liability: Is It a Reasonable Alternative Design to Tennessee's Products Liability Statute?", en University of Memphis Law Review (Vol. 39, 2), pp. 463-503.

Tamayo Jaramillo, Javier (2007): Tratado de responsabilidad civil (Bogotá, Ed. Legis), tomo II.

TARUfFo, Michele (2009): Páginas sobre justicia civil (Traducc. Maximiliano Aramburo Calle, Madrid, Ed. Marcial Pons).

TESTU, François Xavier y MoITRY, Jean-Hubert (1998) : La responsabilité du fait des produits défectueux, Commentaire de la loi 98-389 du 19 mai 1998, en : D. Aff. suppl. au $\mathrm{N}^{\circ} 25$.

Tunc, André (1989): La responsabilité civile (Paris, Economica).

VAlbuena QUiÑones, Gustavo (2011): "La empresa y los productos defectuosos: una especial responsabilidad frente al consumidor", en: De la responsabilidad civil y comercial. Incidencias, en lo mercantil, de los cambios en la legislación civil y reflexiones sobre las S.A.S. (Bogotá, Ed. Dike), pp. 33-49.

VINEY, Geneviève (1998): "L'introduction en droit français de la directive européenne du 25 juillet 1985 relative au fait des produits défectueux", en: Recueil Dalloz Chronique, Cahier 31.

VINEY, Geneviève y JOURDAIN, Patrice (2006): "Les conditions de la responsabilité", en: Ghestin, Jacques, Traité de droit civil (Paris, Ed. LGDJ).

VINEY, Geneviève (2002): "L'interprétation par la CJCE de la directive du 25 juillet 1985 sur la responsabilité du fait des produits défectueux", en: JCP. La Semaine Juridique (Édition Générale, № 44-45), pp. 1945-1948.

VOIDEY, Nadège (2005): Le risque en droit civil (Aix-en-Provence, Ed. PUAM).

Von WriGHT, Georg-Henrik (2010): La diversidad de lo bueno (Traducc. Daniel González Lagier y Victoria Roca, Madrid, Marcial Pons). 
Wells, Michael H. (1981): "Sindell v. Abbott Laboratories: A New Avenue for DES Litigation", en: 11 Golden Gate U. L. Rev. Disponible en: http://digitalcommons.law.ggu.edu/ggulrev/vol11/iss3/6 [visitado el 20/05/2013].

WajNTRAUB, Javier (2008): Ley de defensa del consumidor, Ley No 24.40 (modif. por leyes 24.568, 24.787, 24.999 y 26.361) en: Gozaíni, Osvaldo Alfredo, Protección procesal de usuarios y consumidores (Buenos Aires, Rubinzal-Culzoni).

WittGenstein, Ludwig (1988): Investigaciones filosóficas (Traducc. Alfonso García Suárez y Ulises Moulines, Barcelona, Crítica).

Woolcott, Olenka (2007): La responsabilidad del productor (Bogotá, Ibáñez). 